\title{
Improvement in renal function in primary hyperparathyroidism following parathyroidectomy
}

\author{
R. R. GHOSE \\ F.R.C.P.E., M.R.C.P.
}

\author{
W. D. MORGAN \\ Ph.D., M.Inst.P.
}

Singleton Hospital, Sketty, Swansea SA2 8QA

\begin{abstract}
Summary
Glomerular filtration rate (GFR) and effective renal plasma flow (ERPF) were measured pre- and postparathyroidectomy in 9 patients with primary hyperparathyroidism. Radiological studies had shown no sign of renal calculi or nephrocalcinosis in these patients. Before operation, GFR ranged from 98.5 to $23.4 \mathrm{ml} / \mathrm{min} / 1.7 \mathrm{~m}^{2}$ and ERPF ranged from 510 to $127 \mathrm{ml} / \mathrm{min} / 1.7 \mathrm{~m}^{2}$. After operation, GFR rose to a range of 108.8 to $48.7 \mathrm{ml} / \mathrm{min} / 1.7 \mathrm{~m}^{2}$, and ERPF ranged from 556 to $189 \mathrm{ml} / \mathrm{min} / 1.7 \mathrm{~m}^{2}$.

The results suggest that early diagnosis and surgery are important, both to prevent progressive renal damage and to improve the possibility of recovery where functional damage has occurred.
\end{abstract}

\section{Introduction}

Relatively few studies have been reported in which renal clearances were performed in primary hyperparathyroidism $\left(1^{\circ} \mathrm{HPT}\right)$ before and after parathyroid surgery. Edvall (1958) estimated glomerular filtration rate (GFR) and effective renal plasma flow (ERPF) in severe $1^{\circ} \mathrm{HPT}$, and observed a fall in both variables when these tests were repeated shortly after parathyroidectomy. However, Freaney, Casey and Muldowney (1978) demonstrated relatively stable creatinine clearances after parathyroidectomy in a group which included severe and mild $1^{\circ} \mathrm{HPT}$. The authors have measured renal function for periods of from 3 months to 4.5 years after ablation of a single adenoma causing hyperparathyroidism, and observed GFR and ERPF in a selected group of 9 patients, from which those presenting with renal calculi were excluded.

\section{Patients and methods}

The patients under consideration presented at Singleton Hospital, Swansea, with a variety of complaints, and were found to have hypercalcaemia on routine biochemical screening. Diagnosis of $1^{\circ} \mathrm{HPT}$ was further investigated by measuring serum calcium and inorganic phosphate concentrations, alkaline phosphatase and immunoreactive parathyroid hor- mone concentration (carboxy terminal fragment Any patient who had a history of renal calculus, ơ ? who had radiological evidence of renal calcificatios was excluded. Nine patients fulfilling these criteriag were studied, 5 female and 4 male, with ages ranginio from 16 to 61 years. Two of these patients, M.T. ang D.E., admitted to generalized skeletal pains.

Skeletal X-rays and i.v. urogram were performed i $\vec{a}$ all patients. Skeletal survey was normal in thesê patients with the exceptions of M.T. and D.E. in whom peri-osteal resorption was present. No nephro calcinosis or nephrolithiasis was noted in the uringr $\overrightarrow{\mathrm{b}}$ tract.

Mid-stream urine cultures were sterile in patients.

Sustained hypertension, if present, was treate with anti-hypertensive drugs to achieve good BP con trol.

Parathyroid exploration led to the finding of single parathyroid tumour in all patients, the 3 res maining parathyroid glands having been identifie and shown to be normal macroscopically and histologically. Serum calcium, inorganic phosphate. alkaline phosphatase and creatinine concentrations were measured by Technicon Auto-analyser. Venous: blood was obtained in the fasting state from an un 3 constricted vein. Serum immunoreactive parathyroi hormone was assayed by a radio-immunimetric technique which measured the biologically inert caro boxyl fragment of the parathyroid molecule. 0.8 $\mathrm{ng} / \mathrm{ml}$ was the upper limit iof normal using thi method (Addison et al., 1971). GFR and ERPF were estimated simultaneously after intravenous ad $\tilde{N}$ ministration of ${ }^{51} \mathrm{Cr}$ EDTA and ${ }^{125}$ I sodium iodor hippurate, taking venous blood samples at 2 and $\mathbb{R}$ hr after injection (Morgan et al., 1977).

\section{Results}

Pre-operative clinical and biochemical details ar£ summarized in Table 1 . Serum calcium concentra:tion fell into the normal range within $24 \mathrm{hr}$ of para thyroidectomy. Pre- and postoperative values fo serum calcium concentration GFR and ERPF are्ष్ 
given in Table 2. Using Student's paired $t$ test the postoperative fall in serum calcium concentration was significant $(P=0.001)$, and the increase in GFR $(P=0.005)$ and $\operatorname{ERPF}(P=0.02)$ were also significant. There was no significant relationship between preoperative serum calcium concentration and GFR. Mean pre-operative values of GFR and ERPF were reduced to 65 and $73 \%$ respectively of the values expected for subjects of the corresponding age and sex. Postoperatively, GFR and ERPF increased to 81 and $86 \%$ respectively.

Table 2 shows the postoperative/pre-operative percentage change in GFR and ERPF. In 6 of the 9 patients the postoperative GFR rose by $27 \%$ or more

TABLE 1. Initial serum biochemistry on patients with primary hyperparathyroidism (normal ranges in brackets)

\begin{tabular}{|c|c|c|c|c|c|c|}
\hline & $\begin{array}{l}\text { Sex and } \\
\text { age (years) }\end{array}$ & $\begin{array}{c}\text { Clinical } \\
\text { presentation }\end{array}$ & $\begin{array}{c}\text { Serum } \\
\text { calcium } \\
\text { mmol/1 } \\
(2 \cdot 2-2 \cdot 6)\end{array}$ & $\begin{array}{c}\text { Serum } \\
\text { inorganic } \\
\text { phosphate } \\
\text { mmol/1 } \\
(0 \cdot 8-1 \cdot 5)\end{array}$ & $\begin{array}{c}\text { Serum } \\
\text { alkaline } \\
\text { phosphatase } \\
\text { u./1 } \\
(35.5-106 \cdot 5)\end{array}$ & $\begin{array}{c}\text { Serum } \\
\text { parathyroid } \\
\text { hormone } \\
\text { ng/ml } \\
(0-8 \cdot 0)\end{array}$ \\
\hline MT & $\mathbf{F}(52)$ & Hypertension & $3 \cdot 74$ & 0.9 & $198 \cdot 8$ & $6 \cdot 5$ \\
\hline DE & M(62) & $\begin{array}{l}\text { Dyspepsia } \\
\text { without peptic } \\
\text { ulceration }\end{array}$ & $2 \cdot 84$ & $0 \cdot 7$ & $184 \cdot 6$ & $5 \cdot 0$ \\
\hline JH & $\mathbf{M}(25)$ & Aching jaw & $3 \cdot 40$ & 0.5 & $127 \cdot 8$ & $0 \cdot 7$ \\
\hline EM & $F(55)$ & $\begin{array}{l}\text { Paraesthesia } \\
\text { in fingers }\end{array}$ & $3 \cdot 16$ & 0.9 & 54 & 0.9 \\
\hline CG & $M(62)$ & Chest pain & $3 \cdot 38$ & $0 \cdot 7$ & $139 \cdot 2$ & 0.9 \\
\hline VH & $F(58)$ & $\begin{array}{l}\text { Fatigue and } \\
\text { weight loss }\end{array}$ & $3 \cdot 13$ & $0 \cdot 6$ & $56 \cdot 8$ & $2 \cdot 5$ \\
\hline EP & $F(48)$ & $\begin{array}{l}\text { Pain and } \\
\text { swelling in } \\
\text { left knee }\end{array}$ & $2 \cdot 93$ & $0 \cdot 9$ & $120 \cdot 7$ & $0 \cdot 6$ \\
\hline KG & $M(16)$ & $\begin{array}{l}\text { Recurrent } \\
\text { abdominal pain }\end{array}$ & $3 \cdot 33$ & $0 \cdot 5$ & $106 \cdot 5$ & $0 \cdot 6$ \\
\hline MB & $F(38)$ & Hypertension & $2 \cdot 93$ & $0 \cdot 7$ & $46 \cdot 9$ & $2 \cdot 4$ \\
\hline
\end{tabular}

TABLe 2. Pre- and postoperative serum calcium concentration, GFR and ERPF

\begin{tabular}{|c|c|c|c|c|c|c|c|}
\hline & \multicolumn{3}{|c|}{ Pre-operative results } & \multirow[b]{2}{*}{$\begin{array}{l}\text { Time } \\
\text { interval }\end{array}$} & \multicolumn{3}{|c|}{ Postoperative results } \\
\hline & $\begin{array}{c}\begin{array}{c}\text { Serum } \\
\text { calcium } \\
\mathrm{mmol} / 1 \\
n=2 \cdot 0-2 \cdot 6\end{array} \\
\text { mal }\end{array}$ & $\begin{array}{c}\text { GFR } \\
\mathrm{ml} / \mathrm{min} / 1 \cdot 7 \mathrm{~m}^{2} \\
n-(\text { see note })\end{array}$ & $\begin{array}{c}\text { ERPF } \\
\mathrm{ml} / \mathrm{min} / 1.7 \mathrm{~m}^{2} \\
n-(\text { see note })\end{array}$ & & $\begin{array}{c}\begin{array}{c}\text { Serum } \\
\text { calcium } \\
\mathrm{mmol} / 1 \\
n=2 \cdot 2-2 \cdot 6\end{array} \\
\end{array}$ & $\begin{array}{c}\text { GFR } \\
\mathrm{ml} / \mathrm{min} / 1.7 \mathrm{~m}^{2} \\
n-(\text { see note })\end{array}$ & $\begin{array}{c}\text { ERPF } \\
\mathrm{ml} / \mathrm{min} / 1 \cdot 7 \mathrm{~m}^{2} \\
n-(\text { see note })\end{array}$ \\
\hline & $3 \cdot 74$ & $23 \cdot 4$ & 136 & $\begin{array}{c}1.5 \text { years } \\
4 \text { years }\end{array}$ & $2 \cdot 45$ & $\begin{array}{l}37 \cdot 9 \\
37 \cdot 2\end{array}$ & $\begin{array}{l}175 \\
192\end{array}$ \\
\hline & $2 \cdot 84$ & $34 \cdot 1$ & 127 & 4.5 years & $2 \cdot 50$ & $48 \cdot 7$ & 189 \\
\hline & $3 \cdot 40$ & $80 \cdot 2$ & - & $\begin{array}{l}1 \text { month } \\
0.5 \text { year }\end{array}$ & $2 \cdot 27$ & $\begin{array}{l}108 \cdot 8 \\
107 \cdot 3\end{array}$ & $\begin{array}{l}556 \\
475\end{array}$ \\
\hline & $3 \cdot 16$ & $60 \cdot 4$ & 510 & 1.5 year & $2 \cdot 39$ & $79 \cdot 5$ & 413 \\
\hline & $3 \cdot 38$ & $70 \cdot 0$ & 402 & $\begin{array}{l}1 \text { month } \\
3 \text { month }\end{array}$ & $2 \cdot 32$ & $\begin{array}{l}89 \cdot 9 \\
80 \cdot 3\end{array}$ & $\begin{array}{l}413 \\
353\end{array}$ \\
\hline & $3 \cdot 13$ & $60 \cdot 0$ & 325 & 5 years & $2 \cdot 50$ & $76 \cdot 2$ & 484 \\
\hline & $2 \cdot 93$ & $71 \cdot 3$ & 351 & 6 months & 2.38 & $77 \cdot 3$ & 426 \\
\hline & $3 \cdot 33$ & $91 \cdot 5$ & 480 & 4.5 years & $2 \cdot 35$ & $98 \cdot 2$ & 633 \\
\hline & $2 \cdot 93$ & $98 \cdot 5$ & 455 & 1 year & $2 \cdot 32$ & $94 \cdot 7$ & 441 \\
\hline Mean ( \pm one s.d.) & $3 \cdot 20 \pm 0 \cdot 29$ & $65 \cdot 5 \pm 24 \cdot 6$ & $348 \pm 148$ & & $2 \cdot 39 \pm 0.08$ & $79 \cdot 0 \pm 23 \cdot 0$ & $397 \pm 151$ \\
\hline
\end{tabular}

$n=$ normal range/value.

GFR (Glomerular filtration rate): Normal male value $=157 \cdot 8-1 \cdot 16 \times($ age in years $)$. Normal female value $=146 \cdot 0-1 \cdot 07 \times($ age in years).

ERPF (Effective renal plasma flow): Normal male value $=841 \cdot 0-6 \cdot 44 \times($ age in years $) ;$ Normal female value $=760 \cdot 0-6 \cdot 44 \times($ age in years). 
above the pre-operative value, in one case (M.T.) increasing by $62.0 \%$. In the other 3 there was no significant change.

In 5 of the 8 patients in whom ERPF was measured pre- and postoperatively these values rose by 21.4 to $49 \%$. In the other 3 cases there was either a fall or no significant change. There is no predictable correlation between GFR and ERPF percentage changes.

TABLE 3. Post- and pre-operative percentage change in renal function

\begin{tabular}{lcc}
\hline & $\begin{array}{c}\text { GFR } \\
\mathrm{ml} / \mathrm{min} / 1.7 \mathrm{~m}^{2} \\
n-(\mathrm{see} \text { note })\end{array}$ & $\begin{array}{c}\text { ERPF } \\
\mathrm{ml} / \mathrm{min} / 1 \cdot 7 \mathrm{~m}^{2} \\
n-(\mathrm{see} \text { note })\end{array}$ \\
\hline M.T. & 62.0 & 28.6 \\
D.E. & 48.2 & 48.7 \\
J.H. & 35.7 & - \\
E.M. & 31.8 & -19 \\
C.G. & 28.4 & -2.5 \\
V.H. & 27.0 & +49 \\
E.P. & 8.4 & +21.4 \\
K.G. & 7.3 & +31.9 \\
M.B. & -3.9 & -2.5 \\
\hline
\end{tabular}

$n=$ normal range/value.

GFR (Glomerular filtration rate): Normal male value $=157 \cdot 8-1 \cdot 16 \times($ age in years $)$;

Normal female value $=146.0-1.07 \times$ (age in years $)$.

ERPF (Effective renal plasma flow): Normal male value $=841 \cdot 0-6.44 \times($ age in years $)$;

Normal female value $=760 \cdot 0-6.44 \times($ age in years $)$.

\section{Discussion}

It is striking that the 2 patients M.T. and D.E., with evidence of osteitis fibrosa and with the highest levels of circulating PTH, had the worst renal function pre-operatively and showed the greatest increase in GFR following surgery. Presumably, correction of serum calcium concentration was not the most important factor as the pre-operative serum calcium concentration was $2.84 \mathrm{mmol} / \mathrm{l}$ in D.E., and $3.74 \mathrm{mmol} / \mathrm{l}$ in M.T. The factors concerned with the postoperative improvement in renal function cannot be ascertained. No renal histology was obtained in these patients and therefore it cannot be established that regression of structural changes occurred. Furthermore, although correction of serum calcium concentration, of PTH and of serum alkaline phosphatase occurred postoperatively, it is not clear as to which of these factors were important in the reducduction of renal function.

A wide range of renal dysfunction was noted at presentation in these patients. Reduction in GFR and ERPF is likely to result from structural changes within the kidney, although direct effects of excessive
PTH or hypercalcaemia may be contributory气̊ Percutaneous renal biopsy findings have beer described from a patient with $1^{\circ} \mathrm{HPT}$ who presente\& with a creatinine clearance of $17 \mathrm{ml} / \mathrm{min}$. Intravenous. urogram, as in the present patients, showed no sigr of nephrocalcinosis or nephrolithiasis. Renal histol: ogy showed marked destruction of renal parenchymot with fibrosis, patchy infiltration and chronic inflam $\frac{\bar{\sigma}}{\overline{5}}$ matory cells, and numerous amorphous calciun deposits. Tubules were severely atrophied, but glo merular changes were also marked, with hyalinizaes tion, tuft congestion, and fibrous thickening of Bowman's capsule (Evans and Zutshi, 1962).

Parathyroidectomy was associated with an im pressive rise in GFR in 6 patients. When only sligh reduction of renal function was initially present, was apparent that complete recovery of renal function was possible but not inevitable after operation, $v$ Likewise, of Edvall's (1958) 20 patients who wers studied pre- and postoperatively, there were 4 with minimal renal dysfunction who were restored to nor $\infty$ mal renal function after parathyroidectomy. Sixteers of Edvall's patients with moderate or severe renat impairment showed a decline in renal function aftex parathyroidectomy, yet 4 of these patients who were re-studied at a later date demonstrated som造 improvement.

Significant recovery of renal function is possi@i $\vec{\emptyset}$ in $1^{\circ} \mathrm{HPT}$ after parathyroidectomy, and eafy parathyroid exploration is advocated to conse and improve existing renal function.

\section{Acknowledgments}

We are grateful to Mr J. S. Waters and Mr H. S. WinseyQ for expert parathyroid surgery; Dr A. M. Joekes for critica comments on the paper; Sister M. Morris for pre- and post operative nursing management; and to Miss J. E. Davies for secretarial assistance.

\section{References}

Addison, G.N., Hales, C.N., Woodhead, J.S. \& O'Rear $\frac{3}{\text { - }}$. DON, J.L.H. (1971) Immunoradiometric assay of parathy roid hormone. Journal of Endocrinology, 49, 521.

Edvall, C.A. (1958) Renal function in hyperparathyroidism a clinical study of thirty cases with special reference to selective renal clearance and renal vein catheterization. Acta chirurgica scandinavica, (Suppl 229).

Evans, B. \& ZUTSHI, D. (1962) Hyperparathyroidism revealed by renal biopsy. British Medical Journal, 1, 1739.

Freaney, R., Casey, O.M. \& Muldowney, F.P. (1978) The long-term effect of parathyroidectomy on renal function $N$ Irish Journal of Medical Science, 147, 205.

Morgan, W.D., Birks, J.L., Sivyer, A. \& Ghose, R.R N (1977) An efficient technique for the simultaneous estima tion of GFR and ERPF involving a single injection and two blood samples. International Journal of Nuclear Medi cine and Biology, 4, 79. 